\title{
Acute and sub-acute toxicity profile of crude extract and fractions of Gymnema sylvestre
}

\author{
Rofiyat Omolara Raji', Hadiza Lami Muhammad, Abdulkadir Abubakar, Sophia Shekwoyan Maikai and \\ Habibat Feyishara Raji
}

\begin{abstract}
Background: Gymnema sylvestre is a reputable medicinal plant commonly explore for the management of diabetes and other ailments in traditional medicine. In the present study, we investigated the phytochemical compositions and effect of crude extract, hexane, and ethyl-acetate fractions of Gymnema sylvestre on biochemical and hematological parameters of Wistar rats.

Methods: Albino rats were distributed randomly into a control group and nine treatment groups orally administered crude extract and fractions of Gymnema sylvestre (100, 300, and $600 \mathrm{mg} / \mathrm{kg} \mathrm{BW}$ ) for 21 days. Liver and kidney function indices, as well as hematological parameters, were monitored.

Results: Our results revealed that the crude methanol extract contains flavonoids $(8.56 \pm 0.50 \mathrm{mg} / \mathrm{g})$, alkaloids $(13.84 \pm 0.67 \mathrm{mg} / \mathrm{g})$, total phenol $(1.98 \pm 0.50 \mathrm{mg} / \mathrm{g})$, saponins $(23.85 \pm 0.35 \mathrm{mg} / \mathrm{g})$ and tannins $(16.00 \pm 0.34 \mathrm{mg} / \mathrm{g})$. The crude methanol, ethyl acetate and n-hexane fractions of Gymnema sylvestre had $\mathrm{LD}_{50}$ greater than $5000 \mathrm{mg} / \mathrm{kg}$ BW in acute oral toxicity test. The extract and fractions at 300 and $600 \mathrm{mg} / \mathrm{kg}$ BW cause loss of body weight of the rats, significantly altered $(p<0.05)$ the levels of biochemical indices including the aspartate transaminases, alanine transaminase, alkaline phosphates, bilirubin, proteins, urea, creatinine, and white blood cells (WBC) counts when compared with the non-treated control. However, the extract and fractions at $100 \mathrm{mg} / \mathrm{kg}$ BW did not cause any significant $(p>0.05)$ alterations to the levels of biochemical and hematological parameters when compared with the non-treated control.

Conclusion: Gymnema sylvestre at sub-acute doses of 300 and $600 \mathrm{mg} / \mathrm{kg}$ BW could compromise the functional integrity of the rats' liver and kidney. The study, therefore, suggested the use of Gymnema sylvestre for oral remedy at a dose of $100 \mathrm{mg} / \mathrm{kg}$ or below.
\end{abstract}

Keywords: Acute and sub-acute toxicity, Gymnema sylvestre, Biochemical, Hematological

\section{Background}

Medicinal plants have been globally used in folk medicine for the management and treatments of several diseases. With an estimate of about $80 \%$ of the world's population relying on medicinal plants to meet their primary health care needs [1]. Medicinal plants offer

\footnotetext{
* Correspondence: rofiyatraji22@gmail.com

Department of Biochemistry, Federal University of Technology, Minna, Niger State P.M.B. 65, Nigeria
}

\section{Springer Open}

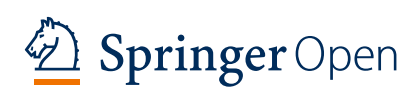

attractive opportunities for drug discovery and development [2]. Furthermore, a myriad of these plants commonly used in traditional medical systems has been scientifically validated for their biological activities in in vitro and in vivo models. However, despite the growing scientific evidence of the therapeutic efficacy of medicinal plants [3], studies have indicated that the biological activities of some of these plants are concomitantly associated with adverse effects on the biological system, especially when consumed over a long period of

(C) The Author(s). 2021 Open Access This article is licensed under a Creative Commons Attribution 4.0 International License, which permits use, sharing, adaptation, distribution and reproduction in any medium or format, as long as you give appropriate credit to the original author(s) and the source, provide a link to the Creative Commons licence, and indicate if changes were made. The images or other third party material in this article are included in the article's Creative Commons licence, unless indicated otherwise in a credit line to the material. If material is not included in the article's Creative Commons licence and your intended use is not permitted by statutory regulation or exceeds the permitted use, you will need to obtain permission directly from the copyright holder. To view a copy of this licence, visit http://creativecommons.org/licenses/by/4.0/. 
time $[4,5]$. Therefore, the safety evaluation of medicinal plants intended for use as oral remedies holds an important aspect of drug development from the natural products. The safety of these plants is, however, further jeopardized by the unhygienic and unethical processing, lack of quality controls, appropriate labeling and dosage [6]. Herbal consumers, therefore, need to be informed of the safety and appropriate use of these plants. Consequently, studies aimed at contributing to the scanty information on the possible toxic effects of these plants on the biological system are increasing [7]. Furthermore, in vivo acute, sub-acute, chronic, and sub-chronic toxicity studies are the most widely accepted experimental strategies for assessing the safety or toxicity of medicinal plants as data generated from these studies holds a translational relevance in humans.

Gymnema sylvestre is an indigenous herb of the Apocynaceae family commonly found in Africa, India, China, and Australia [8]. It is a reputable medicinal plant commonly used in traditional medicine for the treatment of diabetes, obesity, cancer, asthma, cardiovascular diseases, and several other diseases [9-13]. Gymnemasaponins and gymnemic acids are the most recognized phytoconstituents of Gymnema sylvestre [12, 14]. The leaves of this plant contain resin, flavonoid, phytin, alkaloids, tartaric acid, anthraquinones, phenols, tannins, stigmasterol, cardiac glycosides, quinones, hentriacontane, lupeol, pentatriacontane, and $\beta$-amyrin [15-17]. Pharmacologically, different extracts from Gymnema sylvestre have been reported for various biological activities including antidiabetic [18-20], antioxidants [21], antimicrobial [22], anti-obesity [23], hepatoprotective [24], anti-inflammatory [25], and anticancer [26] activities. Although this plant has been proven therapeutically valuable both in the traditional medical system and experimental studies, literature survey revealed scanty scientific information on its safety and toxicity to the biological system. The objective of this study is, therefore, to investigate the effects of oral administration of crude methanol, ethyl acetate, and n-hexane fractions of Gymnema sylvestre by monitoring its effects on function indices of liver and kidney, and hematological parameters of albino rats.

\section{Methods}

\section{Plant sample collection and extraction}

The whole plant Gymnema sylvestre plant was collected from Bida farm in Niger State. The plant was identified and authenticated at the National Research Institute for Chemical Technology, Zaria. A voucher specimen, number NARICT/1613 was deposited at the Institute's herbarium for future reference. The plant was rinsed under clean running water, air-dried, and pulverized. The powdered sample was stored in an airtight container until it is ready for use. Six hundred gram $(600 \mathrm{~g})$ of powdered Gymnema sylvestre plant sample was extracted with methanol (2.5 l) using a reflux extractor. The crude extract yield was $5 \%$. The crude extract $(30 \mathrm{~g})$ was partitioned between $\mathrm{n}$-hexane $(1500 \mathrm{~mL})$ and ethyl acetate $(600 \mathrm{~mL})$ using a separating funnel to yield $\mathrm{n}$-hexane (1.03\%) and ethyl acetate (2.4\%) fractions which were concentrated using a rotary evaporator. The concentrated extract and fractions were stored in a refrigerator at $4{ }^{\circ} \mathrm{C}$.

\section{Analysis of phytochemical compositions}

The total flavonoid contents of the crude extract were estimated using a spectrophotometer based on the formation of a flavanoid-aluminum complex that absorbs maximally at $415 \mathrm{~nm}$ [27]. Total phenol was estimated using Folin-Ciocalteu reagent protocol [28]. The total alkaloids were quantitatively estimated spectrophotometrically at $565 \mathrm{~nm}$ using vincristine as standard [29]. The tannin content was determined using the Folin Denis reagent. The amount of tannin was calculated as tannic acid equivalent from the standard curve [30]. A gravimetric method of AOAC [31], was used for saponin determination in the samples.

\section{In vivo acute and sub-acute toxicity study Experimental animals}

Adult albino rats (Mean weight $=126.45 \pm 3.45 \mathrm{~g}$ ) were obtained from the animals holding unit of Department of Biochemistry, Benue State University, Nigeria. The in vivo animal experiments was conducted in strict compliances with the principles governing the use of laboratory animals as laid out by the Federal University of Technology, Minna Committee on Ethics for Medical and Scientific Research as contained in the Animal Care Guidelines and Protocol Review of National Institutes of Health Guide for the Care and Use of Laboratory Animals (NIH Publication No. 85-23, 1985).

\section{Acute toxicity}

The acute oral toxicity test of the crude methanol extract, and n-hexane and ethylacetate fractions of Gymnema sylvestre were evaluated in albino rats using Lorke's method as reported by Muhammad et al. [32].

\section{Subacute toxicity}

A total of fifty albino rats were randomly assigned into ten [10] groups of 5 rats each. Based on our previous study which indicated that Gymnema sylvestre exhibited therapeutic activities at doses range of $100 \sim 600 \mathrm{mg} / \mathrm{kg}$ $\mathrm{BW}$, we selected 3 doses within the range for our subacute toxicity study. Single daily doses of 100,300 , and $600 \mathrm{mg} / \mathrm{kg} \mathrm{BW}$ of each crude extract, n-hexane, and ethyl acetate fractions of Gymnema sylvestre were 
administered to groups 1-9 while the 10th group served as the control group and received $0.5 \mathrm{ml}$ of normal saline. All treatments were administered orally once daily using an oral cannula for 21 days. The rats were observed daily for any signs of toxicity, and their body weights were recorded throughout the experimental period.

\section{Collection of blood samples}

The collection of blood sample for biochemical and hematological analyses were as described previously [33, 34]. Briefly, after the 21th extract administrations, the animals were fasted overnight but had free access to water. The animals were then euthanized using diethyl ether and the blood samples were collected by cardiac puncture into heparinized and non-heparinized bottles and process [35], for hematological and biochemical investigations respectively.

\section{Analysis of biochemical parameters}

All biochemical analyses were conducted using the Randox Diagnostic kit (Randox Laboratories Ltd., Crumlin, UK). Alanine transaminase (ALT) was analyzed on the principle of the catalytic action of ALT on alanine and $\alpha$ - oxoglutarate to form pyruvate and glutamate [36]. Aspartate transaminase (AST) was measured by monitoring the concentration of oxaloacetate hydrazone formed with 2, 4 - dinitrophenylhydrazine [37]. Serum total protein concentration was estimated based on the principle that cupric ions in an alkaline medium interact with protein peptide bonds resulting in the formation of a colored complex which absorbed maximally at $546 \mathrm{~nm}$ [38]. The bilirubin assay was based on the reaction between bilirubin and diazotized sulphanilic acid in an alkaline medium to form a blue colored complex which absorbed at $578 \mathrm{~nm}$ [39]. Albumin concentration was assayed based on its quantitative binding to the indicator 3, 3', 5, 5'-tetrabromo-cresol sulphonephthalein (bromocresol green, BCG) [40]. The albumin-BCG-complex absorbs maximally at $578 \mathrm{~nm}$, the absorbance is directly proportional to the concentration of albumin in the sample. For creatinine assay, creatinine in alkaline solution reacts with picric acid to form a colored complex [41]. The amount of the complex formed is directly proportional to the creatinine concentration. Urea on the other one was estimated spectrophotometrically based on Berthelot's reaction; urea hydrolysis to ammonia in the presence of urease [42].

\section{Analysis of hematological parameters}

The hematological parameters including hemoglobin concentrations, levels of packed cell volume (PCV) the red blood cells (RBC) counts, white blood cells (WBC) counts, mean-corpuscular hemoglobin [43], mean corpuscular volume (MCV), mean corpuscular hemoglobin concentration (MCHC) were estimated using automated hematologic analyzer (Sysmex, KX-21, Japan) as described by Dacie and Lewis [44].

\section{Data analysis}

All analysis was conducted in triplicate and analyzed using statistical package for social science (SPSS) version 16 and presented as means \pm standard error of the mean. One-way analysis of variance (ANOVA) at $p<$ 0.05 were used for comparing the significant differences between treatment groups.

\section{Results}

Preliminary phytochemical compositions and acute toxicity

The crude methanol extract of G. sylvestre whole plant contains flavonoids $(8.56 \pm 0.50 \mathrm{mg} / \mathrm{g})$, alkaloids $(13.84 \pm$ $0.67 \mathrm{mg} / \mathrm{g})$, total phenol $(1.98 \pm 0.50 \mathrm{mg} / \mathrm{g})$, saponins $(23.85 \pm 0.35 \mathrm{mg} / \mathrm{g})$ and tannins $(16.00 \pm 0.34 \mathrm{mg} / \mathrm{g})$ (Table 1). The crude methanol, ethyl acetate and nhexane fractions of Gymnema sylvestre had $\mathrm{LD}_{50}$ greater than $5000 \mathrm{mg} / \mathrm{kg}$ BW in acute oral toxicity test (Table 2).

Effect of crude extract and fractions of Gymnema sylvestre on hematological parameters in wister rats

There were no significant differences $(p>0.05)$ in RBC, $\mathrm{PCV}, \mathrm{HB}, \mathrm{MCV}$, and $\mathrm{MCHC}$ of all extract-treated groups when compared with the control group. White blood cell concentrations on the other hand decrease $(p<0.05)$ in all treatment groups compared to the control (Table 3).

Effect of crude extract and fractions of Gymnema sylvestre on serum biochemical parameters in albino rats

The concentrations of AST, ALT, ALP, bilirubin, and proteins concentrations were significantly higher in the serum of rats treated with 300 and $600 \mathrm{mg} / \mathrm{kg} \mathrm{BW}$ when compared with the control, while those treated with 100 $\mathrm{mg} / \mathrm{kg}$ body weight compared well $(p>0.05)$ with the control (Fig. 1, 2, 3, 4 and 5). All the doses of crude methanol and n-hexane fraction of Gymnema sylvestre significantly decreases the serum albumin concentrations

Table 1 Qualitative and quantitative phytochemical constituents of methanol extract of $G$. sylvestre whole plant

\begin{tabular}{lll}
\hline Phytochemical constituents & Qualitative & Quantitative $\mathbf{( m g / g )}$ \\
\hline Flavonoids & + & $8.56 \pm 0.50$ \\
Total phenol & + & $1.98 \pm 0.50$ \\
Alkaloids & + & $13.84 \pm 0.67$ \\
Saponins & + & $23.85 \pm 0.35$ \\
Tannins & + & $16.00 \pm 0.34$ \\
\hline
\end{tabular}


Table 2 Acute oral toxicity of Gymnema sylvestre plant extracts in rats

\begin{tabular}{|c|c|c|c|}
\hline $\begin{array}{l}\text { Dose }(\mathrm{mg} / \mathrm{kg} \\
\text { bodyweight) }\end{array}$ & Extract & $\begin{array}{l}\text { Number of } \\
\text { death }\end{array}$ & $\begin{array}{l}\text { Behavioral } \\
\text { changes }\end{array}$ \\
\hline \multicolumn{4}{|l|}{ Phase 1} \\
\hline \multirow[t]{3}{*}{10} & $\begin{array}{l}\text { Crude } \\
\text { methanol }\end{array}$ & $0 / 3$ & none \\
\hline & N-hexane & $0 / 3$ & none \\
\hline & Ethylacetate & $0 / 3$ & none \\
\hline \multirow[t]{3}{*}{100} & $\begin{array}{l}\text { Crude } \\
\text { methanol }\end{array}$ & $0 / 3$ & none \\
\hline & n-hexane & $0 / 3$ & none \\
\hline & Ethylacetate & $0 / 3$ & none \\
\hline \multirow[t]{3}{*}{1000} & $\begin{array}{l}\text { Cude } \\
\text { methanol }\end{array}$ & $0 / 3$ & none \\
\hline & n-hexane & $0 / 3$ & none \\
\hline & Ethylacetate & $0 / 3$ & none \\
\hline \multicolumn{4}{|l|}{ Phase 2} \\
\hline \multirow[t]{3}{*}{1600} & $\begin{array}{l}\text { Crude } \\
\text { methanol }\end{array}$ & $0 / 3$ & none \\
\hline & n-hexane & $0 / 3$ & none \\
\hline & Ethylacetate & $0 / 3$ & none \\
\hline \multirow[t]{3}{*}{2900} & $\begin{array}{l}\text { Crude } \\
\text { methanol }\end{array}$ & $0 / 3$ & none \\
\hline & n-hexane & $0 / 3$ & none \\
\hline & Ethylacetate & $0 / 3$ & none \\
\hline \multirow[t]{3}{*}{5000} & $\begin{array}{l}\text { Crude } \\
\text { methanol }\end{array}$ & $0 / 3$ & none \\
\hline & n-hexane & $0 / 3$ & none \\
\hline & Ethylacetate & $0 / 3$ & none \\
\hline
\end{tabular}

when compared with the normal control group, while those treated with 300 and $600 \mathrm{mg} / \mathrm{kg}$ bodyweight of ethyl acetate fraction shows a higher concentration of albumin when compared with their parental counterpart (Fig. 6). Among the treatment concentrations tested, only $600 \mathrm{mg} / \mathrm{kg} \mathrm{BW}$ of the extract and fractions significantly decreases the serum urea concentration (Fig. 7) while increasing serum creatinine (Fig. 8) concentrations when compared with the control counterpart.

\section{Effect of crude extract and fractions of Gymnema sylvestre on body weight changes of albino rats}

There was significant loss of bodyweight in rats treated with 300 and $600 \mathrm{mg} / \mathrm{kg} \mathrm{BW}$ of crude extract and fractions of Gymnema sylvestre when compared with the control group and those treated with $100 \mathrm{mg} / \mathrm{kg} \mathrm{BW}$ of the crude extract and fractions (Table 4).

\section{Discussion}

Recently, much attention has been focused on using natural products as an alternative therapy for the treatment of different ailments including diabetes mellitus. Phytochemicals are bioactive plant compounds that are responsible for various biological activities and toxicological virtue [45]. The presence of significant amounts of flavonoids, alkaloids, saponins, tannins, and phenols (Tables 1 and 2) justified the traditional usage of Gymnema sylvestre for lipid-lowering purposes and for treating diabetes and obesity among others. Previous study has also indicated the presence of flavonoids, alkaloids, saponins, tannins, and phenols in methanol extract of Gymnema sylvestre [20]. The antidiabetic effect of this plant have been reportedly linked to different mechanisms involving each of the above-mentioned phytoconstituents [46]. In addition, the flavonoids, alkaloids, saponins, tannins, and phenols identified in the

Table 3 Effect of crude extract and fractions of Gymnema sylvestre on Hematological Parameters in rats

\begin{tabular}{lllllll}
\hline Extract/Dose $(\mathbf{m g} / \mathbf{k g}$ bodyweight) & $\mathbf{H b}(\mathbf{g} / \mathbf{d l})$ & $\mathbf{P C V}(\%)$ & $\mathbf{M C V}(\mathbf{f l})$ & MCHC (g/dl) & RBC $\left(\times 10^{\mathbf{1 2}} \mathbf{d l}\right)$ & $\mathbf{W B C}\left(\times 10^{\mathbf{9}} \mathbf{d l}\right)$ \\
\hline Normal & $14.50 \pm 0.50^{\mathrm{b}}$ & $52.00 \pm 1.00^{\mathrm{b}}$ & $56.50 \pm 1.50^{\mathrm{b}}$ & $30.50 \pm 0.50^{\mathrm{a}}$ & $8.10 \pm 0.60^{\mathrm{a}}$ & $8.00 \pm 1.00^{\mathrm{c}}$ \\
Ethylacetate 100 & $14.00 \pm 2.00^{\mathrm{b}}$ & $52.00 \pm 4.00^{\mathrm{b}}$ & $58.50 \pm 0.50^{\mathrm{c}}$ & $31.50 \pm 2.50^{\mathrm{b}}$ & $7.40 \pm 0.10^{\mathrm{a}}$ & $7.00 \pm 0.50^{\mathrm{b}}$ \\
Ethylacetate 300 & $13.50 \pm 0.50^{\mathrm{a}}$ & $50.00 \pm 1.00^{\mathrm{a}}$ & $57.50 \pm 0.50^{\mathrm{b}}$ & $29.50 \pm 0.50^{\mathrm{a}}$ & $7.70 \pm 0.10^{\mathrm{a}}$ & $7.50 \pm 0.50^{\mathrm{b}}$ \\
Ethylacetate 600 & $15.00 \pm 2.00^{\mathrm{c}}$ & $49.00 \pm 1.00^{\mathrm{a}}$ & $58.50 \pm 0.50^{\mathrm{c}}$ & $31.50 \pm 1.50^{\mathrm{b}}$ & $8.25 \pm 0.35^{\mathrm{a}}$ & $6.50 \pm 0.50^{\mathrm{ab}}$ \\
N-hexane 100 & $14.50 \pm 0.50^{\mathrm{b}}$ & $52.00 \pm 0.01^{\mathrm{b}}$ & $57.50 \pm 0.50^{\mathrm{b}}$ & $31.00 \pm 1.00^{\mathrm{b}}$ & $8.00 \pm 0.40^{\mathrm{a}}$ & $7.00 \pm 0.50^{\mathrm{b}}$ \\
N-hexane 300 & $14.00 \pm 0.10^{\mathrm{b}}$ & $50.50 \pm 0.50^{\mathrm{a}}$ & $57.50 \pm 0.50^{\mathrm{b}}$ & $31.50 \pm 1.50^{\mathrm{b}}$ & $7.30 \pm 0.40^{\mathrm{a}}$ & $7.50 \pm 0.50^{\mathrm{b}}$ \\
N-hexane 600 & $15.00 \pm 3.00^{\mathrm{c}}$ & $50.00 \pm 1.00^{\mathrm{a}}$ & $56.50 \pm 0.50^{\mathrm{a}}$ & $30.50 \pm 1.50^{\mathrm{a}}$ & $7.90 \pm 0.10^{\mathrm{a}}$ & $5.50 \pm 0.50^{\mathrm{a}}$ \\
Crude 100 & $14.50 \pm 0.50^{\mathrm{b}}$ & $51.50 \pm 3.50^{\mathrm{b}}$ & $57.50 \pm 2.50^{\mathrm{b}}$ & $31.00 \pm 0.01^{\mathrm{b}}$ & $8.20 \pm 0.40^{\mathrm{a}}$ & $7.50 \pm 0.50^{\mathrm{b}}$ \\
Crude 300 & $14.50 \pm 2.50^{\mathrm{b}}$ & $49.50 \pm 0.50^{\mathrm{a}}$ & $58.50 \pm 0.50^{\mathrm{c}}$ & $31.50 \pm 1.50^{\mathrm{b}}$ & $7.55 \pm 0.50^{\mathrm{a}}$ & $7.00 \pm 0.01^{\mathrm{b}}$ \\
Crude 600 & $13.50 \pm 0.50^{\mathrm{a}}$ & $52.50 \pm 0.50^{\mathrm{b}}$ & $58.50 \pm 0.50^{\mathrm{c}}$ & $31.50 \pm 2.50^{\mathrm{b}}$ & $7.90 \pm 0.10^{\mathrm{a}}$ & $5.50 \pm 0.50^{\mathrm{a}}$ \\
\hline
\end{tabular}

Data are Mean \pm SEM of triplicate determinations. Mean with different superscripts alphabet differ significantly $(p<0.05)$. Key: $\mathrm{Hb}=$ hemoglobin, $\mathrm{PCV}=$ packed cell volume, $\mathrm{MCV}=$ mean cell volume, $\mathrm{MCHC}=$ mean cell hemoglobin concentration, $\mathrm{RBC}=$ red blood cells, $\mathrm{WBC}=$ white blood cells 


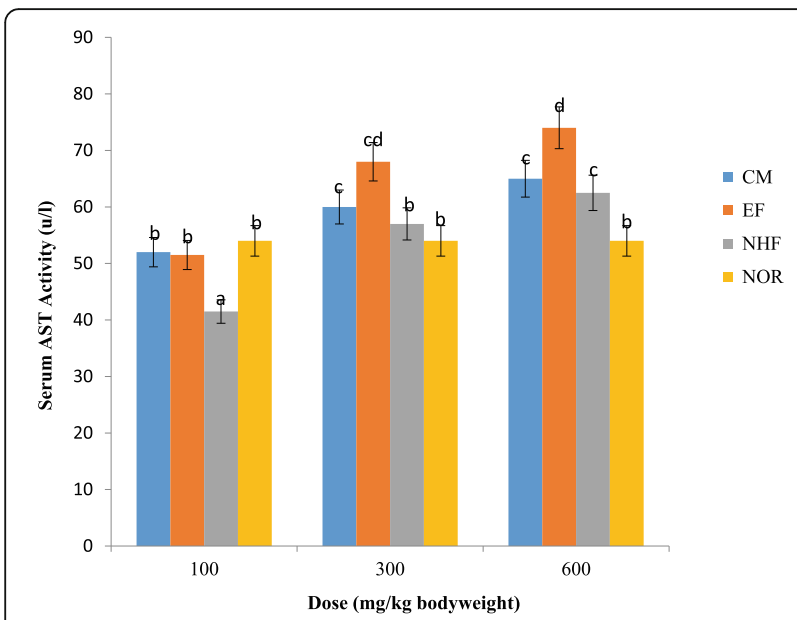

Fig. 1 Effect of crude extract and fractions of Gymnema sylvestre on serum aspartate aminotransferase of rats. Mean with different superscripts differ significantly $(p<0.05)$. Key: NOR: normal control, CM: crude methanol extract, EF: ethyl acetate fraction, NHF: n-hexane fraction

methanol extract of Gymnema sylvestr have been reported for antioxidant, anti-diabetics, anti-cancer, antimicrobial, anti-parasitic, anti-hypertensive, analgesic anti-inflamatory and several other biological activities [47-50]. Though medicinal plants are widely accepted and used in the treatment of many diseases, their toxicity must not be ignored.

However, in addition to the biological activities of the phytochemicals identified in the methanol extract of Gymnema sylvestr, various studies have also linked the toxicity of various plant to the presence of these phytochemicals $[45,47,51]$. It is therefore become relevant to access the safety of Gymnema sylvestr. Acute toxicity is

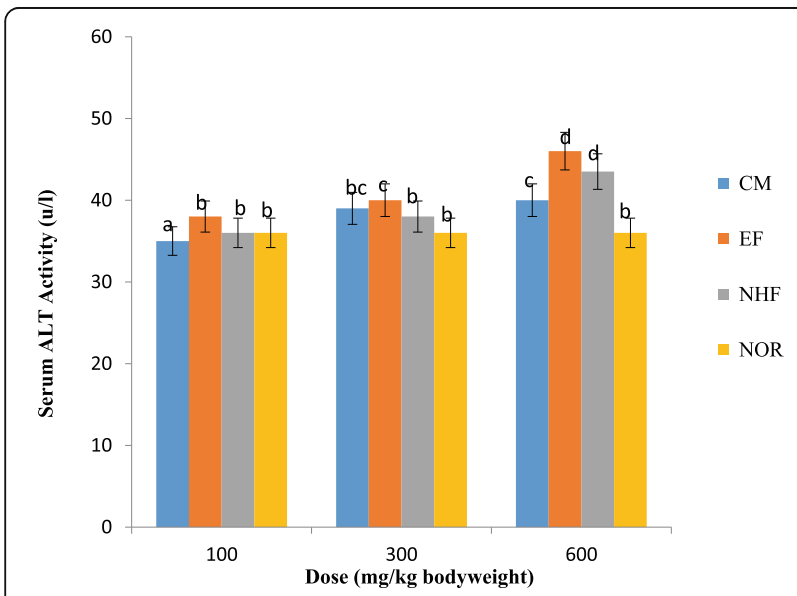

Fig. 2 Effect of crude extract and fractions of Gymnema sylvestre on serum alanine aminotransferase of rats. Mean with different superscripts differ significantly $(p<0.05)$. Key: NOR: normal control, CM: crude methanol extract, EF: ethyl acetate fraction, NHF: n-hexane fraction

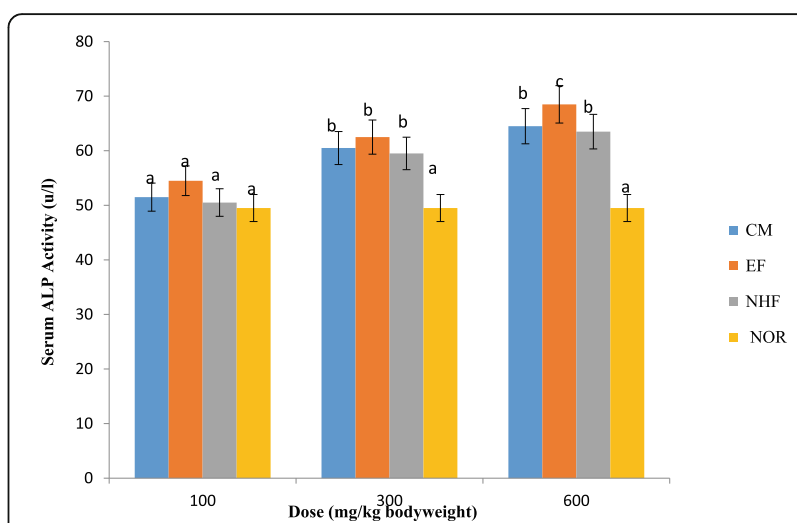

Fig. 3 Effect of crude extract and fractions of Gymnema sylvestre on serum alkaline phosphatase activities of rats. Mean with different superscripts differ significantly $(p<0.05)$. Key: NOR: normal control, $\mathrm{CM}$ : crude methanol extract, EF: ethyl acetate fraction, NHF:

n-hexane fraction

the adverse effects that occur within $24 \mathrm{~h}$ of ingesting a single dose of substance [52]. Results of the present study suggested that the crude extract, n-hexane, and ethyl-acetate fractions of $G$. sylvestre exhibited a high degree of safety with $\mathrm{LD}_{50}$ greater than $5 \mathrm{~kg} / \mathrm{BW}$. Thus can be categorized as non-toxic extract (Class 5) in accordance to the guideline of Organization for Economic Cooperation and Development (OCED) on acute oral toxicity testing based on $\mathrm{LD}_{50}$.

Kifayatullah et al. [32] however, suggested that plant extract with the high safety profile in the acute study may elicit toxic effect to the biological system upon subacute administration, therefore, a plant extract that is commonly used for long term management of diseases like diabetes, cancer, and high blood pressure must be further evaluated for its safety in the sub-acute treatment regime. Sub-acute toxicity is the toxicity that

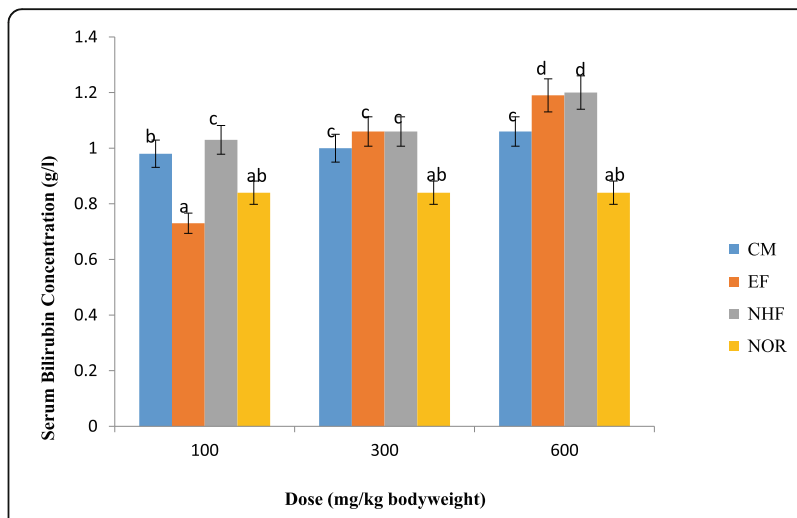

Fig. 4 Effect of crude extract and fractions of Gymnema sylvestre on serum bilirubin concentrations of rats. Mean with different superscripts differ significantly $(p<0.05)$. Key: NOR: normal control, CM: crude methanol extract, EF: ethyl acetate fraction, NHF: n-hexane fraction 


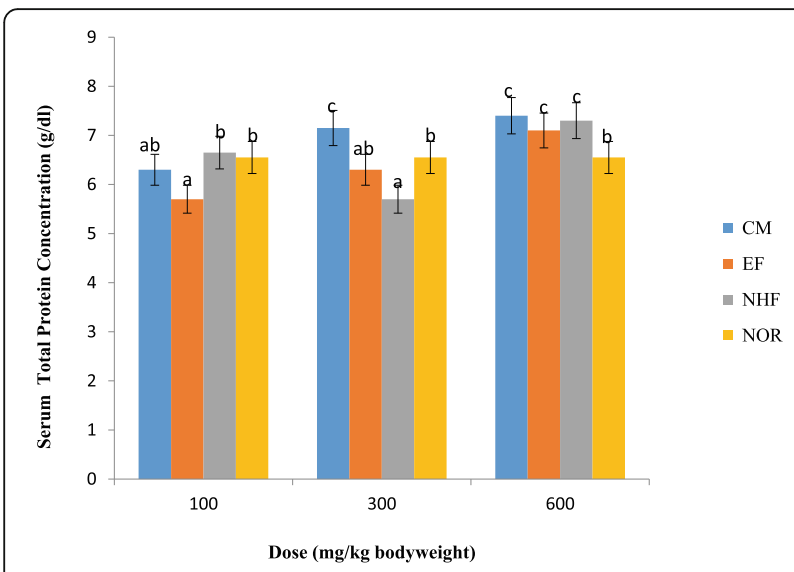

Fig. 5 Effect of crude extract and fractions of Gymnema sylvestre on serum total proteins concentrations of rats. Mean with different superscripts differ significantly $(p<0.05)$. Key: NOR: normal control, CM: crude methanol extract, EF: ethyl acetate fraction, NHF: n-hexane fraction

manifests over repeated and long term dosing of a substance, drug, or plant extract [53]. Therefore, as Gymnema sylvestre is reportedly used for long term management of diabetes, we evaluated its safety for such use.

Adverse effects arising from sub-acute plant administrations manifest on vital organs especially the liver and kidney due to their involvement in the metabolism of the substance [54]. Therefore, evaluation of biochemical parameters holds a pivotal position in assessing the

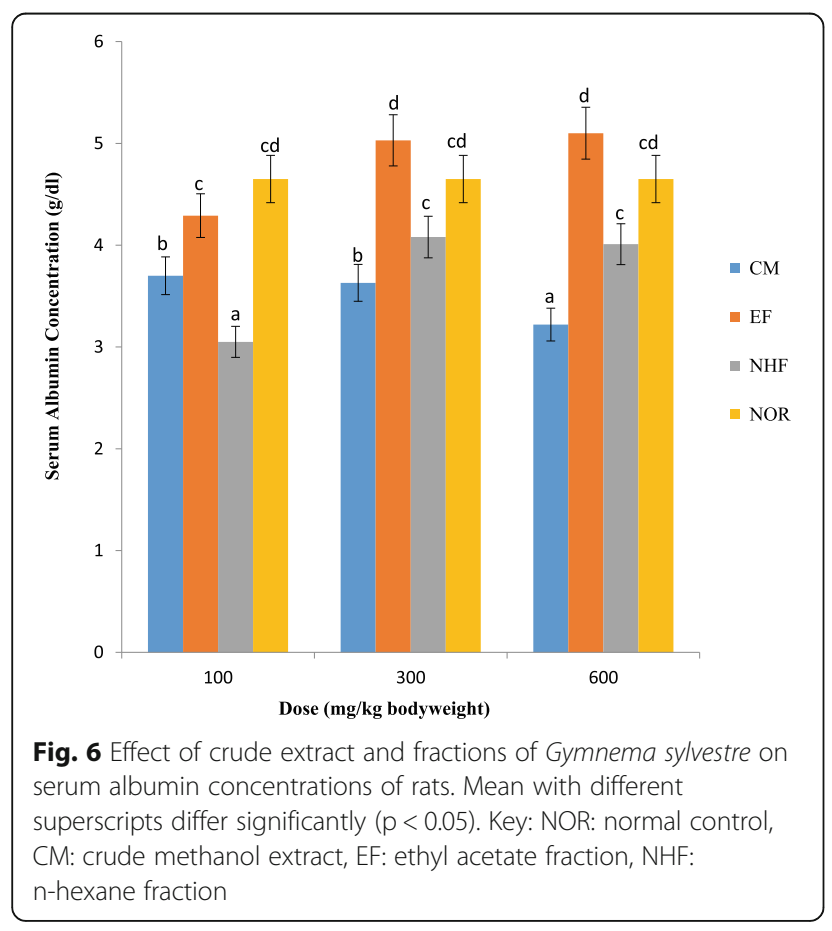

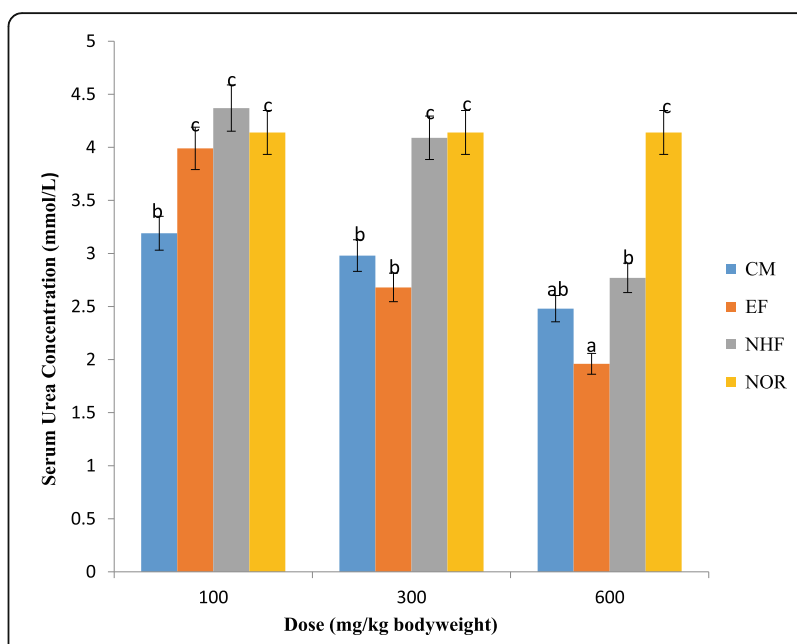

Fig. 7 Effect of crude extract and fractions of Gymnema sylvestre on serum urea concentrations of rats. Mean with different superscripts differ significantly ( $p<0.05)$. Key: NOR: normal control, CM: crude methanol extract, EF: ethyl acetate fraction, NHF: n-hexane fraction

integrity of the liver and kidney following possible assault from repeated administration of plant extract.

The most relevant and widely used biochemical parameters in assessing liver integrity include AST, ALT, ALP, total proteins, albumins, and bilirubins $[55,56]$. These enzymes and proteins were primarily found in the liver and are released in a substantial amount to the serum when the liver's integrity has been compromised $[57,58]$. Consequently, 21 days' administrations of crude methanol, ethyl acetate, and n-hexane fractions of

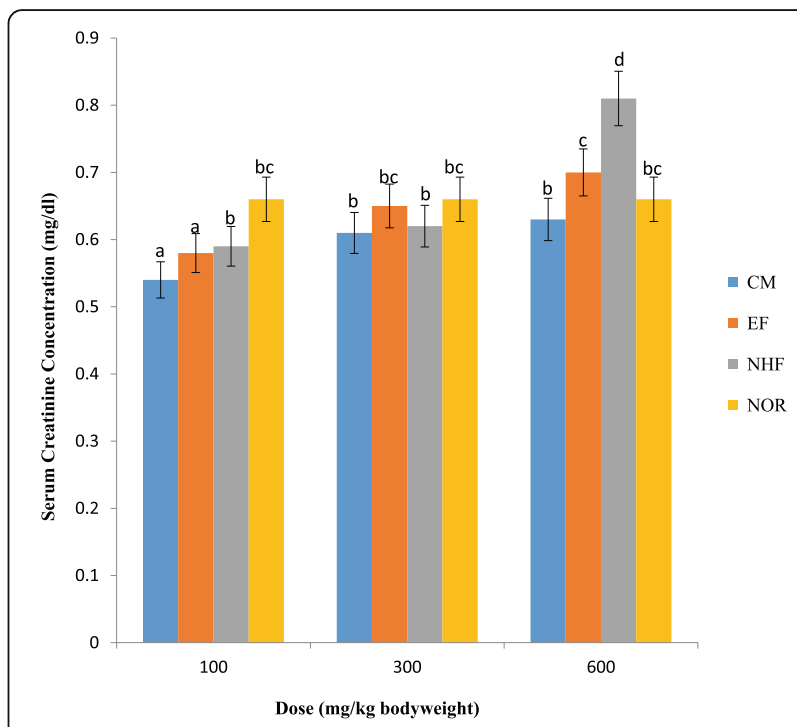

Fig. 8 Effect of crude extract and fractions of Gymnema sylvestre on serum creatinine concentrations of rats. Mean with different superscripts differ significantly $(p<0.05)$. Key: NOR: normal control, CM: crude methanol extract, EF: ethyl acetate fraction, NHF: n-hexane fraction 
Table 4 Effect of crude extract and fractions of Gymnema sylvestre on bodyweight gain of albino rats

\begin{tabular}{llll}
\hline Weight & Before Treatment & After treatment & Weight gain/loss \\
\hline Normal & $182.07 \pm 11.28$ & $192.58 \pm 12.63$ & 10.51 \\
crude100mg/kgbw & $164.32 \pm 11.09$ & $161.17 \pm 8.44$ & 3.15 \\
crude300mg/kgbw & $143.60 \pm 5.42$ & $127.25 \pm 6.83$ & -16.35 \\
crude600mg/kgbw & $152.97 \pm 4.11$ & $136.61 \pm 0.45$ & -16.36 \\
ethylacetate100mg/kgbw & $152.49 \pm 16.98$ & $157.09 \pm 16.26$ & 4.60 \\
ethylacetate300mg/kgbw & $125.81 \pm 5.18$ & $122.20 \pm 4.34$ & -3.61 \\
ethylacetate600mg/kgbw & $164.52 \pm 5.02$ & $160.56 \pm 6.12$ & -3.96 \\
nhexane100mg/kgbw & $178.87 \pm 0.52$ & $184.75 \pm 3.13$ & 5.88 \\
nhexane300mg/kgbw & $142.89 \pm 12.19$ & $140.66 \pm 4.99$ & -2.23 \\
nhexane600 & $166.32 \pm 3.96$ & $170.34 \pm 2.26$ & 4.02
\end{tabular}

Data are Mean \pm SEM of triplicate determinations

Gymnema sylvestr at 300 and $600 \mathrm{mg} / \mathrm{kg}$ BW significantly upregulated the activities of AST, ALT, ALP, total proteins, and bilirubin in the serum of albino rats when compared with the non-treated control. As mentioned earlier, these upregulations of biochemical indices of liver integrity are secondary events that follow liver assault. The bioactive components in the Gymnema sylvestr crude extract and fractions must have interacted and assaulted the liver cells through a yet unidentified mechanism. However, it is clear from these findings that Gymnema sylvestr at sub-acute doses of 300 and 600 assaulted the liver and thus should be discouraged for use as an oral remedy at a dosing of $300 \mathrm{mg} / \mathrm{kg} \mathrm{BW}$ or above.

Urea and creatinine are important excretory metabolites and are widely accepted clinical markers of kidney integrity [59]. Unfortunately, treatments of albino rats with crude methanol, ethyl acetate, and n-hexane fraction of Gymnema sylvestre at $600 \mathrm{mg} / \mathrm{kg}$ significantly decrease the serum urea concentration (Fig. 7) while increasing serum creatinine (Fig. 8) concentrations when compared with the control counterpart. This alteration is an indication of a compromised kidney function, the altered protein metabolism and expression as observed above (Fig. 3) could be implicated in the observed trends of urea concentrations following the sub-acute extract administrations. Coherently with our findings, previous studies from our lab $[60,61]$ and others [34] have also reported significant alterations in the levels of urea and creatinine following sub-acute dosing of plant extract at a dose of $600 \mathrm{mg} / \mathrm{kg} \mathrm{BW}$ or above.

As a carrier of genetic materials, nutrients, metabolites across the body, the hematopoietic system is one of the most important systems in human and are most susceptible to assaults by toxic substances, including toxic metabolite from plant extracts $[62,63]$. Fortunately, there was no significant difference in $\mathrm{RBC}, \mathrm{PCV}, \mathrm{HB}, \mathrm{MCV}$, and $\mathrm{MCHC}$ counts in rats treated with crude methanol, ethyl acetate, or n-hexane fraction of Gymnema sylvestre when compared with the non-treated control, suggesting that Gymnema sylvestre even at high dose does not mediate erythropoietic tendency of the animals. In line with our observation, Muhamed et al. [64] reported that the hematological profile of rats dosed $N$. campestris was not different from the control counterparts. However, the significant decrease in white blood cell (WBC) counts following treatments with $600 \mathrm{mg} / \mathrm{kg} \mathrm{BW}$ crude extract and fraction suggested exhaustion of immune cells as a result of its engagement to ameliorate the stress induced by the bio-active components of the extract [63]. This will affect the animals' ability to fight further infection and thus compromise the overall health status of the animal.

According to Berinyuy et al. [62] loss of body weight is a reliable indicator of toxicity of a compound or plant extract. Consequently, our biochemical findings on Gymnema sylvestre at 300 and $600 \mathrm{mg} / \mathrm{kg}$ BW was further strengthened by the loss of body weight of rats treated with 300 and $600 \mathrm{mg} / \mathrm{kg}$ BW of crude extract and fractions. This loss of body weight could be attributed to altered metabolism or loss of appetite, resulting in in-adequate feed intake and consequently loss of tissue protein. Its however noteworthy, that the aberrant expression and activities of biochemical parameters and WBC counts observed in rats treated with 300 and 600 $\mathrm{mg} / \mathrm{kg} \mathrm{BW}$ of crude methanol, ethyl acetate, or $\mathrm{n}$ hexane fractions of Gymnema sylvestre were completely absent in rats treated with $100 \mathrm{mg} / \mathrm{kg} \mathrm{BW}$ dose. Thus indicating the safety of this plant for both acute and subacute administration at $100 \mathrm{mg} / \mathrm{kg}$ BW.

\section{Conclusion}

In conclusion, administration of crude methanol, ethyl acetate, and n-hexane fractions of Gymnema sylvestre at sub-acute doses of 300 and $600 \mathrm{mg} / \mathrm{kg} \mathrm{BW}$ significantly altered the serum biochemical parameters in rats. 
However, rats dosed with the same extracts at $100 \mathrm{mg} /$ $\mathrm{kg} \mathrm{BW}$ are devoid of biochemical anomalies when compared with the control counterpart. This study therefore, suggested the use of Gymnema sylvestre at dose of 100 $\mathrm{mg} / \mathrm{kg}$ or below.

\author{
Abbreviations \\ ANOVA: Oneway analysis of variance; DMRT: Duncan's Multiple Range Test: \\ SEM: Standard error of mean; AST: aspartate transaminases; ALT: alanine \\ transaminase; ALP: alkaline phosphates; HB: hemoglobin; PCV: packed cell \\ volume; RBC: red blood cells; WBC: white blood cells; $\mathrm{MCH}$ : mean- \\ corpuscular hemoglobin; MCV: mean corpuscular volume; MCHC: mean \\ corpuscular hemoglobin concentration (MCHC)
}

\section{Acknowledgements}

The authors would like to appreciate the technical staff of Biochemistry Laboratory Federal University of Technology Minna, for their kind assistances.

\section{Authors' contributions}

All authors participate in research design. Author ROR, SSM \& HFR conducted the research work and write the manuscript. Author HLM supervised the work and revised the manuscript while authors AA co-supervised and revised the work. All authors read and approved the final manuscript.

\section{Funding}

This is a self-sponsored mTech research work.

\section{Availability of data and materials}

All data are presented in the manuscript.

\section{Declarations}

Ethics approval and consent to participate

The animal experiment was conducted in strict compliances with the principles for humane handling and use of laboratory animals as contained in the Animal Care Guidelines and Protocol Review of National Institutes of Health Guide for the Care and Use of Laboratory Animals (NIH Publication No. $85-23,1985)$.

\section{Consent for publication}

Not applicable.

\section{Competing interests}

The authors declared no conflict of interest exist.

Received: 5 December 2020 Accepted: 1 June 2021

Published online: 23 June 2021

\section{References}

1. Ekor M. The growing use of herbal medicines: issues relating to adverse reactions and challenges in monitoring safety. Front Pharmacol. 2014;4:177.

2. Ugwah-Oguejiofor CJ, Okoli CO, Ugwah MO, Umaru ML, Ogbulie CS, Mshelia $\mathrm{HE}$, et al. Acute and sub-acute toxicity of aqueous extract of aerial parts of Caralluma dalzielii N. E. Brown in mice and rats. Heliyon. 2019;5(1): e01179-e.

3. Dias F. Cytogenetic evaluation of the effect of aqueous extracts of the medicinal plants Alpinia nutans Rosc.(Zingiberaceae) and Pogostemun heyneanus Benth.(Labiatae) on Wistar rats and Allium cepa Linn.(Liliaceae) root tip cells. Brazil J Genet. 1994;17:175-80.

4. Ertekin V, Selimoğlu MA, Altinkaynak S. A combination of unusual presentations of Datura stramonium intoxication in a child: rhabdomyolysis and fulminant hepatitius. J Emerg Med. 2005;28(2):227-8. https://doi.org/1 0.1016/j.jemermed.2004.11.006.

5. Koduru S, Grierson D, Afolayan A. Antimicrobial activity of Solanum aculeastrum. Pharm Biol. 2006;44(4):283-6. https://doi.org/10.1080/138802 00600714145

6. Raynor DK, Dickinson R, Knapp P, Long AF, Nicolson DJ. Buyer beware? Does the information provided with herbal products available over the counter enable safe use? BMC Med. 2011;9:94.
7. Yuet Ping K, Darah I, Chen Y, Sreeramanan S, Sasidharan S. Acute and subchronic toxicity study of Euphorbia hirta L. methanol extract in rats. BioMed Res Inter. 2013;2013:182064.

8. Christopoulos MV, Rouskas D, Tsantili E, Bebeli PJ. Germplasm diversity and genetic relationships among walnut (Juglans regia L.) cultivars and Greek local selections revealed by inter-simple sequence repeat (ISSR) markers. Scientia Hort. 2010;125(4):584-92. https://doi.org/10.1016/j.scienta.2010.05. 006.

9. Tiwari P, Mishra BN, Sangwan NS. Phytochemical and pharmacological properties of Gymnema sylvestre: an important medicinal plant. BioMed Res Inter. 2014;2014:830285.

10. Singh VK, Umar S, Ansari SA, lqbal M. Gymnema sylvestre for diabetics. J Herbs, Spices Med Plant. 2008;14(1-2):88-106. https://doi.org/10.1080/104 96470802341508.

11. Tiwari P, Mishra BN, Sangwan NS. Phytochemical and pharmacological properties of $<i>$ Gymnema sylvestre $</ i>$ : an important medicinal plant. BioMed Res Inter. 2014;2014:830285.

12. Khan F, Sarker MMR, Ming LC, Mohamed IN, Zhao C, Sheikh BY, et al. Comprehensive Review on Phytochemicals, Pharmacological and Clinical Potentials of Gymnema sylvestre. Front Pharmacol. 2019;10:1223-.

13. Mathew M. Aromatic and medicinal plants Research Station, Odakkali-a Centre for Promoting Medicinal and Aromatic Plants. Indian Coconut JCochin. 2004;34(10):10-5.

14. Khramov V, Spasov A, Samokhina M. Chemical composition of dry extracts of Gymnema sylvestre leaves. Pharm Chem. 2008;42(1):29-31. https://doi. org/10.1007/s11094-008-0051-8.

15. Sinsheimer JE, Rao GS, Mcllhenny HM. Constituents from Gymnema sylvestre leaves $\mathrm{V}$ : isolation and preliminary characterization of the gymnemic acids. J Pharm Sci. 1970;59(5):622-8. https://doi.org/10.1002/jps.2 600590510.

16. Patel MR. Pharmacognostic and phytochemical evaluation of Gymnema sylvestre leaf. World J Pharm Pharm Sci. 2017;6(7):1532-8.

17. Senthilkumar M. Phytochemical screening and antibacterial activity of Gymnema sylvestre r. br. ex schult. Inter J Pharm Scie and Res. 2015;6(6): 2496.

18. Kothe A, Uppal R. Antidiabetic effects of Gymnema sylvestre in NIDDM-a short study. INDIAN J Homoeopathic Med. 1997;32:61-2.

19. Kumar P, Rani S, Arunjyothi B, Chakrapani P, Rojarani A. Evaluation of antidiabetic activity of Gymnema sylvestre and Andrographis paniculata in streptozotocin induced diabetic rats. Int J Pharmacogn Phytochem Res. 2017;9:22-5.

20. Mann A, Babalola SB, editors. Hypoglycemic and Hypolipidemic Effects of Gymnema sylvestre in Alloxan Induced Diabetic Rattus Norvergicus2019.

21. Rachh P, Patel S, Hirpara H, Rupareliya M, Rachh M, Bhargava A, et al. In vitro evaluation of antioxidant activity of Gymnema sylvestre r. br. Leaf extract. Rom J Biol Plant Biol. 2009;54(2):141-8.

22. Gunasekaran V, Srinivasan S, Rani SS. Potential antioxidant and antimicrobial activity of Gymnema sylvestre related to diabetes. J Med Plants. 2019;7(2):05-11.

23. Kazemipoor M, Cordell GA, Sarker MMR. Radzi CwJBWM, Hajifaraji M, En Kiat P. alternative treatments for weight loss: safety/risks and effectiveness of anti-obesity medicinal plants. Int J Food Prop. 2015;18(9):1942-63. https:// doi.org/10.1080/10942912.2014.933350.

24. Srividya A, Varma SK, Dhanapal S, Vadivelan R, Vijayan P. In vitro and in vivo evaluation of hepatoprotective activity of Gymnema sylvestre. International Journal of Pharmaceutical Sciences and Nanotechnology. 2009;2(4):768-73.

25. Kumar AR, Rathinam K, Kumar CA. Evaluation of Antiinflammatory activity of some selected species of Asclepiadaceae Family. Int J Chem Sci. 2012;10(1): $548-56$.

26. Srikanth A, Maricar S, MM LN, Kumar R, Baig MR. Anticancer activity of Gymnema sylvestre R. Br Inter J Pharm Sci Nanotech. 2010;3(1):897-9.

27. Sofowora A. Research on medicinal plants and traditional medicine in Africa. Journal of alternative and complementary medicine (New York, NY). 1996;2(3):365-72.

28. Hagerman AE, Riedl KM, Jones GA, Sovik KN, Ritchard NT, Hartzfeld PW, et al. High molecular weight plant polyphenolics (tannins) as biological antioxidants. J Agric Food Chem. 1998;46(5):1887-92. https://doi.org/10.1 021/jf970975b.

29. Trease G. Trease and Evans. Pharmacognosy, A Physician's Guide to Herbal Medicine. 1989;13:912.

30. Makkar HPS, Blümmel M, Borowy NK, Becker K. Gravimetric determination of tannins and their correlations with chemical and protein precipitation 
methods. J Sci Food Agric. 1993;61(2):161-5. https://doi.org/10.1002/jsfa.274 0610205.

31. Midkiff VC. The history of feed analysis, as chronicled in the development of AOAC official methods, 1884-1984. Journal - Association of Official Analytical Chemists. 1984;67(5):851-60.

32. Kifayatullah M, Mustafa MS, Sengupta P, Sarker MMR, Das A, Das SK. Evaluation of the acute and sub-acute toxicity of the ethanolic extract of Pericampylus glaucus (lam.) Merr. In BALB/c mice. J Acute Dis. 2015;4(4): 309-15. https://doi.org/10.1016/j.joad.2015.06.010.

33. Olugbodi JO, David O, Oketa EN, Lawal B, Okoli BJ, Mtunzi F. Silver Nanoparticles Stimulates Spermatogenesis Impairments and Hematological Alterations in Testis and Epididymis of Male Rats. Molecules. 2020;25(5).

34. Lawal B, Shittu OK, Oibiokpa FI, Mohammed H, Umar SI, Haruna GM. Antimicrobial evaluation, acute and sub-acute toxicity studies of Allium sativum. J Acute Dis. 2016;5(4):296-301. https://doi.org/10.1016/j.joad.2016. 05.002 .

35. Shittu OK, Lawal B, Alozieuwa BU, Haruna GM, Abubakar AN, Berinyuy EB. Alteration in biochemical indices following chronic administration of methanolic extract of Nigeria bee propolis in Wistar rats. Asian Pacif J Trop Dis. 2015;5(8):654-7. https://doi.org/10.1016/S2222-1808(15)60907-0.

36. De Ritis F, Coltorti M, Giusti G. Serum-transaminase activities in liver disease. Lancet (London, England). 1972;1(7752):685-7.

37. Rej R. Measurement of aminotransferases: part 1. Aspartate aminotransferase. Crit Revi Clin Lab Sci. 1984;21(2):99-186. https://doi.org/1 0.3109/10408368409167137.

38. Gornall AG, Bardawill CJ, David MM. Determination of serum proteins by means of the biuret reaction. J Biol Chem. 1949;177(2):751-66. https://doi. org/10.1016/S0021-9258(18)57021-6.

39. Suzuki Y, Sakagishi Y. Determination of Serum Bilirubin by the Diazo Method Using the Diazotized 3-Nitroaniline Reacting Readily with the Photoproducts of Bilirubin. 臨床化学. 1994;23(2):158-63.

40. Doumas BT, Watson WA, Biggs HG. Albumin standards and the measurement of serum albumin with bromcresol green. Clin Chim Acta. 1971;31(1):87-96. https://doi.org/10.1016/0009-8981(71)90365-2.

41. Delanghe JR, Speeckaert MM. Creatinine determination according to Jaffewhat does it stand for? NDT Plus. 2011;4(2):83-6. https://doi.org/10.1093/ ndtplus/sfa211.

42. Searle PL. The Berthelot or indophenol reaction and its use in the analytical chemistry of nitrogen. A review Analyst. 1984;109(5):549-68. https://doi. org/10.1039/an9840900549.

43. Travers P, Walport M, Shlomchik MJ, Janeway M. Immunobiology: the immune system in health and disease: Churchill Livingstone; 1997.

44. Dacie J, Lewis S. Practical textbook of Haematology 7th edition Edinburgh. Church Livingstone. 1991;7:54-79.

45. Kuete V. Toxicological survey of African medicinal plants; 2014.

46. Kanetkar P, Singhal R, Kamat M. Gymnema sylvestre: A Memoir. J Clin Biochem Nutr. 2007:41(2):77-81. https://doi.org/10.3164/jcbn.2007010.

47. Guldiken B, Ozkan G, Catalkaya G, Ceylan FD, Ekin Yalcinkaya I, Capanoglu E. Phytochemicals of herbs and spices: health versus toxicological effects. Food Chem Tox. 2018;119:37-49. https://doi.org/10.1016/j.fct.2018.05.050.

48. Harsha N, Sridevi V, Lakshmi M, Rani K, Vani NDS. Phytochemical analysis of some selected spices. Int J Innov Res Sci Eng Technol. 2013;2(11):6618-21.

49. Carlsen MH, Halvorsen BL, Holte K, Bøhn SK, Dragland S, Sampson L, et al. The total antioxidant content of more than 3100 foods, beverages, spices, herbs and supplements used worldwide. Nutr J. 2010;9(1):1-11.

50. Arora S, Kaur K, Kaur S. Indian medicinal plants as a reservoir of protective phytochemicals. Teratog Carcinog Mutagen. 2003;23(S1):295-300. https:// doi.org/10.1002/tcm.10055

51. Lu B, Li M, Yin R. Phytochemical content, health benefits, and toxicology of common edible flowers: a review (2000-2015). Crit Rev Food Sci Nutr. 2016; 56(sup1):S130-S48.

52. Amos T, Bashir L, Saba S, Saba M, Mohammed B, Abdulsalam I, et al. Phytochemicals and acute toxicity profile of aqueous and methanolic extracts of Crateva adansonii leaves in Swiss albino rats. Asian J Biochem. 2015;10(4):173-9. https://doi.org/10.3923/ajb.2015.173.179.

53. Akanji MA, Salau AK, Yakubu M. Safety evaluation of aqueous extract of Crateva adansonii leaves on selected tissues of rats. Fount J Nat Appl Sci. 2013;2(1):17-28.

54. Musa T, Isah F. Liver and kidney functional indices of pregnant rats following the administration of the crude alkaloids from Senna alata leaves. Iran J Tox. 2012;6(16):615-25.
55. Lawal B, Shittu OK, Ossai PC, Abubakar AN, Ibrahim AM. Evaluation of antioxidant activity of giant African snail (Achachatina maginata) haemolymph in CCl4-induced hepatotoxixity in albino rats. J Pharm Res Inter. 2015:141-54.

56. Ibrahim J, Kabiru AY, Abdulrasheed-Adeleke T, Lawal B, Adewuyi AH. Antioxidant and hepatoprotective potentials of curcuminoid isolates from turmeric (Curcuma longa) rhizome on CCl4-induced hepatic damage in Wistar rats. J Taibah Unive Sci. 2020;14(1):908-15. https://doi.org/10.1080/1 6583655.2020.1790928.

57. Yusuf AA, Lawal B, Yusuf MA, Adejoke AO, Raji FH, Wenawo DL. Free radical scavenging, antimicrobial activities and effect of sub-acute exposure to Nigerian Xylopia Aethiopica seed extract on liver and kidney functional indices of albino rat. Iran J Tox. 2018;12(3):51-8. https://doi.org/10.32598/ IJT.12.3.516.1.

58. Umar SI, Lawal B, Mohammed BA, Obiekezie Cl, Adewuyi AH, Babalola SB, et al. Antioxidant and antimicrobial activities of naturally occurring flavonoids from M. heterophylla and the safety evaluation in Wistar rats. Iran J Tox. 2019;13(4):39-44. https://doi.org/10.32598/JT.13.4.516.2.

59. Bashir L, Shittu O, Busari M, Sani S, Aisha M. Safety evaluation of giant African land snails (Archachatina maginata) haemolymph on hematological and biochemical parameters of albino rats. J Adv Med Pharm Scie. 2015;3(3): 122-30. https://doi.org/10.9734/JAMPS/2015/16393.

60. Olaniyan JM, Muhammad HL, Makun HA, Busari MB, Abdullah AS. Acute and sub-acute toxicity studies of aqueous and methanol extracts of Nelsonia campestris in rats. J Acute Dis. 2016;5(1):62-70. https://doi.org/10.1016/j.joa d.2015.08.006.

61. Muhammad S, Hassan L, Dangoggo S, Hassan S, Umar K, Aliyu R. Acute and subchronic toxicity studies of kernel extract of Sclerocarya birrea in rats. Sci World J. 2011:6(3):11-4.

62. Berinyuy EB, Lawal B, Olalekan AA, Olalekan IA, Yusuf AA, Sakpe S, et al. Hematological status and organs/body-weight parameters in Wister rats during chronic administration of Cassia occidentalis. Inter Blood Res \& Rev. 2015;4(3):1-7. https://doi.org/10.9734/IBRR/2015/22021.

63. Lawal B, Shittu OK, Abubakar AN, Haruna GM, Sani S, Ossai PC. Haematopoetic effect of methanol extract of Nigerian honey bee (Apis mellifera) propolis in mice. J Coast Life Med. 2015;3(8):648-51. https://doi. org/10.12980/JCLM.3.2015J5-89.

64. Muhammad H, Makun H, Kabiru A, Mann A, Busari M, Abdullah A, et al. In vitro antibacterial activity and in vivo acute toxicological studies of Nelsonia campestris aqueous leaf exrtact. Int J Biochem Res Rev. 2015;7(1):27-35. https://doi.org/10.9734/JBCRR/2015/16081.

\section{Publisher's Note}

Springer Nature remains neutral with regard to jurisdictional claims in published maps and institutional affiliations.

\section{Submit your manuscript to a SpringerOpen ${ }^{\circ}$ journal and benefit from:}

- Convenient online submission

- Rigorous peer review

- Open access: articles freely available online

High visibility within the field

- Retaining the copyright to your article

Submit your next manuscript at $\boldsymbol{\nabla}$ springeropen.com 